\title{
INFLUENCE OF PIRDOT LEAF (SAURAUIA VULCANI, KORTH.) EXTRACT ON THE BLOOD GLUCOSE RATE AND HISTOLOGIC DESCRIPTION OF THE RETINA OF MALE MICE (MUS MUSCULUS STRAIN DDW)
}

\author{
ADILUDDIN HUTAPEA, SALOMO HUTAHAEAN*, AND SYAFRUDDIN ILYAS \\ Department of Biology, Faculty of Mathematics and Natural Sciences, Universitas Sumatera Utara, Medan 20155, Indonesia. \\ Email: salomo@usu.ac.id
}

Received: 07 July 2018, Revised and Accepted: 15 August 2018

\begin{abstract}
Objective: This research aims to collect laboratory data on the influence of pirdot leaf extract on the retina and blood glucose rate.

Method: The mice were classified into 5 groups: A control group without any treatment, a control group treated with a single injection of 125 mg/kg body weight (BW) of alloxan as the diabetes mellitus trigger, and three groups treated with intra-muscular alloxan injection to induce diabetes mellitus, and pirdot leaf extract, i.e., $150 \mathrm{mg} / \mathrm{kg} \mathrm{BW} \mathrm{(P1),} 200 \mathrm{mg} / \mathrm{kg}$ BW (P2), and $250 \mathrm{mg} / \mathrm{kg}$ BW (P3) for 8 weeks. Subsequently, the blood glucose rates of the mice were measured, and histologic grazes of their retina layers were prepared using the paraffin method.
\end{abstract}

Results: The blood glucose rate of the mice treated with $200 \mathrm{mg} / \mathrm{kg} \mathrm{BW} \mathrm{(113.4} \mathrm{mg/dl)} \mathrm{pirdot} \mathrm{leaf} \mathrm{extract} \mathrm{significantly} \mathrm{differed} \mathrm{from} \mathrm{that} \mathrm{of} \mathrm{the} \mathrm{mice} \mathrm{in}$ the diabetes mellitus control group $(364.8 \mathrm{mg} / \mathrm{dl})(\mathrm{p}<0.05)$. The ganglion cell layer of the retina increased by up to $7.59 \mu \mathrm{m}$, which differed from that of the diabetes mellitus group $(3.67 \mu \mathrm{m})(\mathrm{p}<0.05)$ treated with $250 \mathrm{mg} / \mathrm{kg} \mathrm{BW}$ pirdot leaf extract. The external plexiform layer increased to $17.88 \mu \mathrm{m}$, which differed from that of the diabetes mellitus group $(15.71 \mu \mathrm{m})(\mathrm{p}<0.05)$ treated with $150 \mathrm{mg} / \mathrm{kg}$ BW pirdot leaf extract.

Conclusion: The blood glucose rate obtained after treatment with pirdot leaf extract was lower than that of the diabetes mellitus control group.

Keywords: Saurauia vulcani, Antidiabetes, Retinopathy

(C) 2018 The Authors. Published by Innovare Academic Sciences Pvt Ltd. This is an open access article under the CC BY license (http://creativecommons. org/licenses/by/4. 0/) DOI: http://dx.doi.org/10.22159/ajpcr.2018.v11i11.28316

\section{INTRODUCTION}

The international diabetes federation reports that 415 million people worldwide suffer from diabetes mellitus. A total of 8,554,170 cases of diabetes mellitus were found within the age range of 20-79 years old in 2013 , and 172,601 people died from diabetes. The number of diabetes cases increased to $10,021,400$ in 2015 , and 184,985 adults died from diabetes [1]. The diabetes epidemic does not only threaten individual health but also impedes sustainable socioeconomic development.

How to cure diabetes is very complicated because to overcome the impact of diabetes needs the patient's big strategy and self-management [2].

A research found that one-third of patients with diabetes exhibit indications of diabetic retinopathy, and one-tenth of these patients lose their eyesight [3]. Patients with diabetes mellitus type 1 and $60 \%$ of patients with diabetes mellitus type 2 experience retinopathy [4].

Diabetes, which results in diabetic retinopathy, is the cause of blindness among adults and the third cause of death in the United States. Given the same age, patients with diabetes are at least 2.5 times more likely to experience a heart attack than a person without diabetes. Moreover, $75 \%$ of patients with diabetes mellitus die from vascular diseases. Diabetic complications include heart attack, kidney failure, stroke, gangrene, and an increase in intrauterine fetus mortality rate among pregnant women [5].

Pirdot (Saurauia vulcani, Korth.) is well-known among the Karonese and Tobanese people of North Sumatera as a traditional medicinal plant with ealing properties for diabetes and rheumatism. The phytochemical screening results of pirdot leaf show the existence of secondary metabolic compounds, namely alkaloid, flavonoid, saponin, triterpenoid, and tannin, which can decrease blood glucose rate. Thus, research on pirdot leaf as an alternative therapy with low medication cost should be developed.

The current study was conducted to determine the influence of pirdot leaf extract on the blood glucose rate and histologic description of the retina of male mice (Mus musculus strain DDW).

\section{METHODS}

\section{Preparation of extract}

Pirdot leaf extract was prepared in the Organic Chemistry Laboratory of Natural Materials, Department of Chemistry, Faculty of Mathematics and Natural Sciences (FMIPA), Universitas Sumatera Utara (USU). Pirdot leaves were dried and blended using a blender. Then, pirdot leaf powder was macerated in $70 \%$ ethanol solvent and homogenized for $40 \mathrm{~h}$ to obtain the macerate. The macerate (maceration product) was evaporated and condensed using a vacuum rotary evaporator at $40^{\circ} \mathrm{C}[6]$.

\section{Preparation of mice}

Using these experimental animals has been agreed by Animal Research Ethics Committee from Faculty of Mathematics and Natural Science in Universitas Sumatera Utara. This research used 25 male adult mice, aged \pm 2 months, weighing $\pm 25-30$ g, and raised in the Animal Structure Laboratory of the Department of Biology, FMIPA, USU in Medan. The mice were placed in a plastic container with an underlayer of rice husk, which was replaced twice a week. The container was covered with wire. The mice were provided with food and drink once a day ad libitum.

\section{Experimental design}

This research is entitled "Influence of Pirdot Leaf (Saurauia vulcani, Korth.) extract on the Blood Glucose Rate and Histologic Description of the Retina of Male Mice (M. musculus strain DDW)." It used five 
treatments: Two control groups (positive and negative) and three groups with pirdot leaf extract treatment (i.e., groups that were given alloxan and various dosages of pirdot leaf extract). The numbers of treatments and replications in both experiments were in accordance with the formula proposed by Fereder as follows: $(t-1)(n-1) \geq 15$, where $\mathrm{t}=$ treatment group and $\mathrm{n}=$ replication. Each treatment was divided as follows: Treatment 1: Control group (without treatment) for 8 weeks, Treatment 2: Control group with a single injection of alloxan $(125 \mathrm{mg} / \mathrm{kg}$ body weight [BW] of alloxan was administered as the diabetes trigger) for 8 weeks, Treatment 3: Group provided with alloxan $+150 \mathrm{mg} / \mathrm{kg}$ BW of pirdot leaf extract for 8 weeks, Treatment 4: Group provided with alloxan $+200 \mathrm{mg} / \mathrm{kg} \mathrm{BW}$ of pirdot leaf extract for 8 weeks, and Treatment 5: Group was provided with alloxan $+250 \mathrm{mg} / \mathrm{kg}$ BW of pirdot leaf extract for 8 weeks.

\section{Research flow}

The male mice were raised in the Animal Structure Laboratory of the Department of Biology, FMIPA, USU in Medan. Three pirdot leaf extract treatments were prepared for the three groups with extract treatment. Diabetes was induced among the mice in four groups through intramuscular injection of $125 \mathrm{mg} / \mathrm{kg} \mathrm{BW}$ of alloxan. Alloxan compound can cause disfunction of pancreas $\beta$-cell [7]. The mice with a blood glucose rate of $200 \mathrm{mg} / \mathrm{dl}$ were used in the experiment. Then, 150, 200, and $250 \mathrm{mg} / \mathrm{kg} \mathrm{BW}$ of pirdot leaf extract were provided in Treatments I, II, and III, respectively. These treatments $(0.3 \mathrm{~mL}$ pirdot leaf extract) were given orally to the mice for 8 weeks. The blood glucose rate of each mouse was measured. Then, the mice were killed by dislocating their necks to remove the eyes and prepare blood from the retina using the paraffin method and double coloring with hematoxylin-eosin (HE). The histologic structure of the retina was tested through HE staining [8].

\section{Blood preparation procedure}

The right and left eyes of the mice were remove and washed with $0.9 \%$ $\mathrm{NaCl}$ solution. They were soaked in solutions of buffer formalin $10 \%$ (1) and (2) for $1 \mathrm{~h}$ each. Then, the eyes were dehydrated gradually with $70 \%, 80 \%, 90 \%$, and $96 \%$ alcohol for $1 \mathrm{~h}$ and 30 min each and with absolute alcohol (1), (2), and (3) for $1 \mathrm{~h}$ each. As soon as the dehydration process was finished, treatment was followed by purification using xylene (1), (2), and (3) for $60 \mathrm{~min}$ each. The eyeballs were buried in paraffin [9]. Embedding was performed with liquid paraffin (Merck) at $56^{\circ} \mathrm{C}(1)$ and (2) for $2 \mathrm{~h}$ each. Then, blocking in the cassette was chilled in Paraffin apparatus station at $4^{\circ} \mathrm{C}$ for a certain period and attached on mikrotom (Leica). The eyes were then sliced into $4 \mu \mathrm{m}$ width. Then, the mayer's albumin was smeared, and distilled water was dripped on the object glass. Several paraffin tapes were placed on the surface of the distilled water and left to stand for a certain period on the surface of the object glass. The object glass was then moved to the heating table until the paraffin dried. Staining was provided using HE.

\section{Research parameter}

The research parameter observed was the blood sugar rate of the mice, which was measured using a digital blood sugar rate meter with the brand Easy Touch Digital. The mass of the eyeballs was weighed using a digital scale, and the width of the retina layer was measured based on the width of the retinal ganglion cell (RGC) [3] and the outer plexiform layer (OPL) [9].

The picture of RGC was taken using a digital microscope ZEISS AxionvisionSE64 with 40× objective enlargement with an Axio Camera $E R C 5 S$ connected to a computer. The digital pictures were transferred to the Axio Vision 4.8.2 SP3 program by selecting the toolbar, directing it toward the RGC to determine its size.

The picture of OPL was taken using a digital microscope ZEISS AxionvisionSE64 with 40× objective enlargement with an Axio Camera $E R C 5 S$ connected to a computer. The digital pictures were transferred to the Axio Vision 4.8.2 SP3 program by selecting the toolbar, directing it toward the OPL, and recording their sizes.
The data were collected and analyzed using SPSS 22 version [8].

\section{RESULTS}

The research, which was conducted for 8 weeks, presents the male mice's blood sugar rate in Table 1.

The width of the RGC of the mice obtained in the research is presented in Table 2.

This research determined the thickness of the OPL of the male mice's retina as presented in Table 3.

\section{DISCUSSION}

Blood sugar rate of the male mice

The results of the statistical testing show that the pirdot leaf extract of P2 (113.40 \pm 10.36$)$ was significantly different from that of P1 (160.40 \pm 23.33$), K(+)(364.80 \pm 44.21)$, whereas the pirdot leaf extract of P2 $(113.40 \pm 10.36)$ was not significantly different from that of P3 $(128.80 \pm 08.04), \mathrm{K}(-)(133.40 \pm 10.14)$. The pirdot leaf extract of P3 $(128.80 \pm 08.04)$ was significantly different with $\mathrm{K}(+)$

Table 1: Blood sugar rate of male mice

\begin{tabular}{llll}
\hline Group & $\mathbf{n}$ & Blood sugar rate $(\mathbf{m g} / \mathbf{d l})$ & Notation \\
\hline $\mathrm{K}(-)$ & 5 & $133.40 \pm 10.14$ & $\mathrm{ab}$ \\
$\mathrm{K}(+)$ & 5 & $364.80 \pm 44.21$ & $\mathrm{C}$ \\
$\mathrm{P} 1$ & 5 & $160.40 \pm 23.33$ & $\mathrm{~b}$ \\
$\mathrm{P} 2$ & 5 & $113.40 \pm 10.36$ & $\mathrm{a}$ \\
$\mathrm{P} 3$ & 5 & $128.80 \pm 08.04$ & $\mathrm{ab}$ \\
\hline
\end{tabular}

K(-): Control group (without treatment) for 8 weeks, K(+): Control group with a single injection of alloxan $(125 \mathrm{mg} / \mathrm{kg}$ body weight [BW] of alloxan was administered as the diabetes trigger) for 8 weeks, P1: Group provided with alloxan $+150 \mathrm{mg} / \mathrm{kg}$ BW of pirdot leaf extract for 8 weeks, P2: Group provided with alloxan $+200 \mathrm{mg} / \mathrm{kg}$ BW of pirdot leaf extract for 8 weeks, P3: Group was provided with alloxan $+250 \mathrm{mg} / \mathrm{kg}$ BW of pirdot leaf extract for 8 weeks, n: Replication

Table 2: Width of the RGC of the male mice

\begin{tabular}{llll}
\hline Group & $\mathbf{n}$ & RGC Layer $(\boldsymbol{\mu m})$ & Notation \\
\hline $\mathrm{K}(-)$ & 5 & $6.95 \pm 0.80$ & $\mathrm{ab}$ \\
$\mathrm{K}(+)$ & 5 & $3.67 \pm 0.17$ & $\mathrm{a}$ \\
$\mathrm{P} 1$ & 5 & $6.95 \pm 1.13$ & $\mathrm{ab}$ \\
$\mathrm{P} 2$ & 5 & $6.82 \pm 2.99$ & $\mathrm{ab}$ \\
$\mathrm{P} 3$ & 5 & $7.59 \pm 2.28$ & $\mathrm{~b}$ \\
\hline
\end{tabular}

$\mathrm{K}(-)$ : Control group (without treatment) for 8 weeks, $\mathrm{K}(+)$ : Control group with a single injection of alloxan $(125 \mathrm{mg} / \mathrm{kg}$ body weight [BW] of alloxan was administered as the diabetes trigger) for 8 weeks, P1: Group provided with alloxan $+150 \mathrm{mg} / \mathrm{kg}$ BW of pirdot leaf extract for 8 weeks, P2: Group provided with alloxan $+200 \mathrm{mg} / \mathrm{kg}$ BW of pirdot leaf extract for 8 weeks, P3: Group was provided with alloxan $+250 \mathrm{mg} / \mathrm{kg}$ BW of pirdot leaf extract for 8 weeks, n: Replication, RGC: Retinal Ganglion Cell

Table 3: Thickness of the OPL of the male mice

\begin{tabular}{llll}
\hline Group & $\mathbf{n}$ & OPL $(\boldsymbol{\mu m})$ & Notation \\
\hline $\mathrm{K}(-)$ & 5 & $14.28 \pm 0.21$ & $\mathrm{bc}$ \\
$\mathrm{K}(+)$ & 5 & $15.71 \pm 4.16$ & $\mathrm{bc}$ \\
$\mathrm{P} 1$ & 5 & $17.88 \pm 0.57$ & $\mathrm{c}$ \\
$\mathrm{P} 2$ & 5 & $08.10 \pm 2.37$ & $\mathrm{a}$ \\
$\mathrm{P} 3$ & 5 & $11.26 \pm 4.51$ & $\mathrm{ab}$ \\
\hline
\end{tabular}

$\mathrm{K}(-)$ : Control group (without treatment) for 8 weeks, $\mathrm{K}(+)$ : Control group with a single injection of alloxan $(125 \mathrm{mg} / \mathrm{kg}$ body weight [BW] of alloxan was administered as the diabetes trigger) for 8 weeks, P1: Group provided with alloxan $+150 \mathrm{mg} / \mathrm{kg}$ BW of pirdot leaf extract for 8 weeks, P2: Group provided with alloxan $+200 \mathrm{mg} / \mathrm{kg}$ BW of pirdot leaf extract for 8 weeks, P3: Group was provided with alloxan $+250 \mathrm{mg} / \mathrm{kg} \mathrm{BW}$ of pirdot leaf extract for 8 weeks, $\mathrm{n}$ : Replication, OPL: Outer plexiform layer 


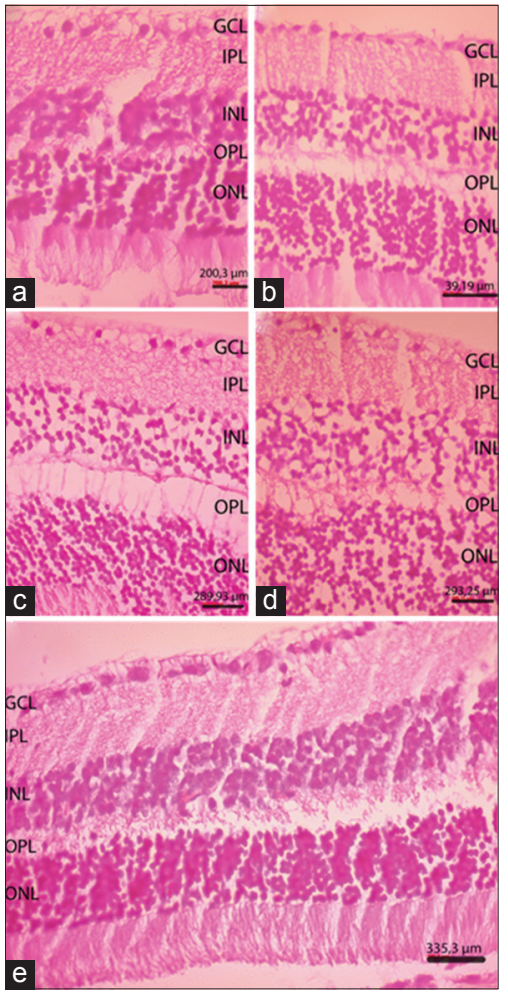

Fig. 1: Incision of the mice's retina with $40 \times$ objective enlargement: (a) Control group without treatment, (b) control group with a single alloxan injection $(125 \mathrm{mg} / \mathrm{kg} \mathrm{BW}$ of alloxan was given as the diabetes trigger) for 8 weeks, (c) group administered with $150 \mathrm{mg} / \mathrm{kg}$ BW pirdot leaf extract, (d) group administered with $200 \mathrm{mg} / \mathrm{kg}$ BW pirdot leaf extract, and (e) group administered with $250 \mathrm{mg} / \mathrm{kg} \mathrm{BW}$ pirdot leaf extract

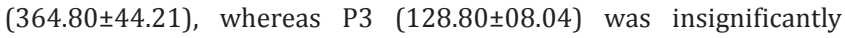
different with $\mathrm{K}(-)(133.40 \pm 10.14), \mathrm{P} 1(160.40 \pm 23.33)$. The pirdot leaf extract in the $200 \mathrm{mg} / \mathrm{mL}$ treatment (P2) achieved the best reduction in mice's blood sugar rate to $113.40 \mathrm{mg} / \mathrm{dL}$ before the eyes were removed, as illustrated in Table 1. The pancreas secretes insulin hormone to control the glucose rate in blood and is influenced by the chemical contents of pirdot leaf extract. The decrease in the mice's blood sugar rate is probably caused by the tannin in pirdot leaf extract [6], which plays a role in glucose absorption [10], and by triterpenoid, which plays a role in insulin secretion [11] to control glucose concentration in blood [12]. Flavonoid is one of the bioactive compounds which functions as an antidiabetic agent preventing carbohydrate metabolism called $\alpha$-amylase and $\alpha$-glucosidase. If $\alpha$-amylase and $\alpha$-glucosidase are inhibited, they can reduce the amount of monosakarida and post-prandial hyperglycemia which will be absorbed by the gut [13]. Furthermore, flavonoid protects lipid membrane from oxidation reaction so that the mass of pancreas $\beta$-cell and insulin can increase [7]. Saponin is one of the compound pirdot leaf extracts decreased the blood glucose rate. Saponin rich-fraction (SRF) upgraded the insulin secretion on healthy $\beta$-cell pancreas [14]. The impact that is caused pirdot leaf extract is not different from metformin antidiabetic medicine [15].

Width of the RGC $(\mu \mathrm{m})$ of the male mice

The results of the statistical test demonstrate that the pirdot leaf extract of P1 $(6.95 \pm 1.13)$ was insignificantly different with $\mathrm{K}(-)$ $(6.95 \pm 0.80)$ and $\mathrm{K}(+)(3.67 \pm 0.17)$ from P2 $(6.82 \pm 2.99)$ and P3 (7.59 \pm 2.28), as shown in Table 2. The treatment that used $250 \mathrm{mg} / \mathrm{mL}$ pirdot leaf extract in P3 significantly increased RGC to $7.59 \mu \mathrm{m}$ with $\mathrm{K}(+)$, and the control group with single alloxan treatment $(125 \mathrm{mg} / \mathrm{kg} \mathrm{BW}$ of alloxan was given as the diabetes trigger) decreased RGC to $3.67 \mu \mathrm{m}$ $(\mathrm{p}<0.05)$. The blocking in the blood flowing to the retina probably decreased the nutrition in every cell, such as ganglion cells, which caused cells to die and the ganglion layer to become thinner. The thinning ganglion layer can cause eyesight disorders because this layer contains neural cells that receive impulses. The RGC layer contains amakrin cells [16] and ganglion neural cells, which are connected to the optic nerve fiber. Blood circulation to the ganglion cells originates from the coroid capillary phlexus, such that the released retinal layers harm the receptor [17]. Consequently, retinal hypoxia reduced the photoreceptor rhodopsin [18] and ischemia caused cell apoptosis in the RGC layer, which was discovered after 2 weeks of hyperglicemy [19]. Meanwhile, cell apoptosis caused the ganglion layer to become thinner. Cell death RGC is related to eyesight loss [9]. One of the contents of pirdot leaf extract, triterpenoid [6], influences insulin formation and secretion, maintains the function of pancreas cell $\beta$, and controls BW, and cholesterol rate [11]. Flavonoid, as an antioxidant, repairs the damaged cell $\beta$ in the mice with diabetes [10]. Therefore, the addition of the mice's RGC may be caused by the triterpenoid and flavonoid contents of pirdot leaf extract. The poor blood circulation can be caused the narrowing arteries, so retinopathy can happen. Retinopathy is known by vitreous bleed [3] and microvascular[19]. However, tannin decrease permeability of the arteries and saponin functioning as wound contraction and epithelization process [20].

\section{Thickness of the OPL of the male mice}

OPL was increased significantly to $17.88 \mu \mathrm{m}$ given treatment P1 $(150 \mathrm{mg} / \mathrm{mL} \mathrm{kg} \mathrm{BW}$ ), as shown in Table 3 . The results of the statistical testing indicated that P1 $(17.88 \mu \mathrm{m})$ was significantly different from P2 $(08.10 \mu \mathrm{m})$ and P3 $(11.26 \mu \mathrm{m})$, whereas P1 $(17.88 \mu \mathrm{m})$ with $\mathrm{K}(-)$ $(14.28 \mu \mathrm{m})$ and $\mathrm{K}(+)(15.71 \mu \mathrm{m})$ was not significantly different. The increase in the retinal plexiform layer was possibly caused by the chemical contents of pirdot leaf extract, such as triterpenoid and flavonoid. Triterpenoid maintained pancreas cell $\beta$ [11], whereas flavonoid repaired pancreas cell $\beta$ [10]. The retinal OPL, RGC, inner plexiform layer (IPL), inner nuclear layer, and outer nuclear layer are illustrated in Fig. 1. The OPL in Groups P2 and P3 decreased more than Group $\mathrm{K}(+)$. Loss in the retinal outer layer causes retinopathy [18]. Tannin, flavonoid, triterpenoid, and saponin that mixed in pirdot leaf extract cause the retina layer instability. However, SRF decreased the island of Langerhans [14]

\section{CONCLUSION}

This research concluded that administering $200 \mathrm{mg} / \mathrm{kg} \mathrm{BW}$ (P2) pirdot leaf extract significantly $(\mathrm{p}<0.05)$ decreased the blood sugar rate of male mice by $113.4 \mathrm{mg} / \mathrm{dl}$. Moreover, administering $250 \mathrm{mg} / \mathrm{kg} \mathrm{BW}$ (P3) pirdot leaf extract increased RGC by $7.59 \mu \mathrm{m}(\mathrm{p}<0.05)$. Finally, administering $150 \mathrm{mg} / \mathrm{kg}$ BW (P1) pirdot leaf extract significantly $(\mathrm{p}<0.05)$ increased OPL by $17.88 \mu \mathrm{m}$.

\section{AUTHOR'S CONTRIBUTIONS}

Adiluddin Hutapea has contributed to collecting the manuscript data and preparing the manuscript. Salomo Hutahaen as a contributor author who suggested the title of the manuscript and Syafruddin Ilyas as contributor author who has guided and reviewed the content of the English Grammar.

\section{CONFLICTS OF INTEREST}

The authors have declared no conflicts of interest.

\section{REFERENCES}

1. American Diabetes Association. Diagnosis and classification of diabetes mellitus. Diab Care 2013;36:67-74.

2. Muha $\mathrm{C}$, Nasee PP. A review article-gestational diabetes mellitus. Inter J Cur Phar Res 2017;9:1.

3. Lai WK, Lo YC. Animal models of diabetic retinopathy: Summary and comparison. J Diab Res 2013;2013:29.

4. Tarr MJ, Kaul K, Chopra M, Kohner ME, Chibber R. Pathophysiology 
of diabetic retinopathy. ISRN Ophth 2012;2013:343560.

5. Price AS, Wilson ML. Pathophysiology: The Clinical Concept of Disease Processes. $6^{\text {th }}$ ed. Jakarta: EGC; 2005.

6. Sitorus P. Characterization simplisia and ethanolic extract of pirdot (Saurauia vulcani, Korth.) leaves and study of antidiabetic effect in alloxan induced diabetic mice. Int J Chem Tech Res 2015;8:792-3.

7. Sari IM, Ilyas S, Widyawati T, Antika AM. Effect of Lawsonia innermis (Linn) leaves ethanolic extract on blood glucose and malondialdehyde level in alloxan-induced diabetic rats. IOP Conf Ser: E Env Sci 2018:130:4-5.

8. Said AM, Zaki EG, Eldin SA, Nasr M, Azab SS, Elzankavalony AY. Efficacy of intravitreal injection of 2-methoxyestradiol in regression of neovascularization of a retinopathy of prematurity rat model. BMC Opht 2017;17:38.

9. Horstmann L, Schimd H, Heinen PA, Kurschus CF, Dick BH, Joachim CS. Inflammatory demyelination induces glia alterations and ganglion cell loss in the retina of an experimental autoimmune encephalomyelitis model. J Neuro 2013;10:120.

10. Das S, Barman S. Antidiabetic and antihyperlipidemic effects of ethanolic extract of leaves of Punica granatum in alloxan-induced noninsulin-dependent diabetes mellitus albino rats. Indian J Pharmacol 2012:44:219-24.

11. Nazaruk J, Borzym-Kluczyk M. The role of triterpenes in the management of diabetes mellitus and its complications. Phytochem Rev 2015;14:675-90

12. Campbell AN, Reece BJ, Mitchell GL. Biology. Jakarta: Erlangga; 2004. p. 142.
13. Dutta J, Kalitta MC. In vitro hypoglicaemic evaluation of seven culinary plants of North East India against Type 2 diabetes. Asian J Pharm Clin Res 2016;9:212.

14. Fitrianda E, Sukandar YE, Adnyana KE. Antidiabetic activity of extract, fractions, and asiaticoside compound isolated from Centella asiatica Linn. Leaves in alloxan-induced diabetic mice. Asian J Pharm Clin Res 2017; 10:269-71.

15. Hutahaean S, Tanjung M, Sari PD, Ningsih EV. Antihyperglycemic and antihyperlipidemic effects of pirdot (Saurauia vulcani Korth.) Leaves extract in mice. IOP Conf Ser: E Env Sci 2018;130:1

16. Markand S, Saul A, Roon P, Prasad P, Martin P, Rozen R, et al. Retinal ganglion cell loss and mild vasculopathy in methylene tetrahydrofolate reductase (Mthfr)-deficient mice: A Model of mild hyperhomocysteinemia. Invest Ophthalmol Vis Sci 2015;56:2684-95.

17. Ganong FW. In: Widjajakusuma DM, editor. Textbook of Medical Physiology. Jakarta: EGC; 2002. p. 321.

18. de Gooyer TE, Stevenson KA, Humphries P, Simpson DA, Gardiner TA, Stitt AW, et al. Retinopathy is reduced during experimental diabetes in a mouse model of outer retinal degeneration. Invest Ophthalmol Vis Sci 2006;47:5561-8.

19. Robinson R, Barathi VA, Chaurasia SS, Wong TY, Kern TS. Update on animal models of diabetic retinopathy: From molecular approaches to mice and higher mammals. Dis Model Mech 2012;5:444-56.

20. Budiman A, Khoeherunnisa R, Tazyinul QA. Wound-healing test of Piper betle leaf extract and Aloe vera in gel preparation. Int J Appl Phar 2018;10:87. 